\title{
Mechanical and Environmental Behavior of Cement Mortars Containing Ladle Furnace Slag
}

\author{
Diego Aponte and Marilda Barra \\ Department of Civil and Environmental Engineering (DECA), Universitat Politècnica de Catalunya- \\ BarcelonaTECH, Campus Nord UPC, 08034-Barcelona, Spain, diego.fernando.aponte@upc.edu
}

\begin{abstract}
At present, steel production is mainly done in basic oxygen furnaces (BOF) and electric arc furnaces (EAF) (Pauliuk, S. et al, 2013, Morfeldt, J. et al, 2015). According to the statistics, it is expected that the use of electric arc furnaces to supply the demand for steel will prevail. In 2017, in Europe, 41\% of steel was produced in electric arc furnaces, while in Spain, according to the Union of Steel Companies (UNESID, 2016), the percentage was almost 66\% in 2016. In 2016 the European Union generated approximately 18.4 Mt of slag (black and white), of which 1.5 Mt was produced in Spain. In other words, the amount of white slag produced was about 286 thousand tons, approximately between 20 and $30 \mathrm{~kg}$ of slag per ton of steel (UNESID, 2016, Euroslag, 2016). Refining slag (white slag) is the second most abundant waste in steel production, and, to date, its final destination is still the landfill. This study has used ladle slag from refined steelworks, as a replacement for cement in different proportions $(0,25,50$ and $75 \%$ ), for the manufacture of mortars. A broad characterization of the ladle slag has been carried out, as well as determining the mechanical, durable, and environmental properties of the manufactured mortars. The results show that using the ladle slag as a replacement for cement produces a decrease in compressive strength, but the expansion behavior remains below the stability limit. It also has been seen that the slag incorporated into mortars, evaluated by leaching test at 28 days, shows inert material behavior.
\end{abstract}

Keywords: Ladle Furnace Slag, Cement Mortars, Durability, and Environmental Impact.

\section{Introduction}

Steel slag is waste that to date has no integral solution, since its properties depend on the raw materials, Steel manufacturing process and the recovery processes carried out. Slags from steel manufacturing can be either from melting or refining processes. The first ones have been subject to more research, as well as regulation. This is because, in 2016, more than $18 \mathrm{Mt}$ of slag (black and white) was generated in the European Union, but they were mostly black slag (UNESID, 2016; Euroslag, 2016).

To date, different studies have been carried out on the possibility of the use of refining slag (white slag) in civil works. Some of the topics studied are: ladle slag as a filler in selfcompacting concretes (Anastasiou, E. et al., 2014, Sideris, K. K. et al., 2018), ladle slag as a cementitious agent in concretes and mortars (Adolfsson, D. et al., 2011, Herrero, T. et al., 2016), ladle slag as a binder in soil stabilization (Manso, J. M. et al., 2005, Ortega-López, V. et al., 2014) and ladle slag as a filler in asphalt mixtures (Skaf, M. et al., 2016). In the studies mentioned above, the durability problems due to the expansion of white slag are present, and it is an aspect that does not have an easy resolution. On the other hand, there are few works related to the environmental impact of slag in cement-based materials (Loncnar, M. et al., 2016, Pantazopoulou, E. et al., 2018). 
Therefore, more research is still necessary to clarify the effect of ladle furnace slag when used in cement-based materials, due to its expansive behavior and its problems with the release of contaminant elements. In this context, the main goal of this study is to analyze the incorporation of fine ladle FURNACE slag in mortars in different rates $(0,25 \%, 50 \%$, and $75 \%$ ), and its influence in mechanical properties, expansion behavior and environmental impact (leaching test).

\section{Materials and Testing Methods}

The materials used for the experimental campaign are basically: (i) CEM I 52.5R Portland Cement, (ii) slag from the refining process of an electric arc furnace Steel plant, and (iii) limestone sand with a particle size between 0 to $5 \mathrm{~mm}$. Potable water is used for the manufacture of mortars, and MiliQ water (obtained by filtering distilled water through a Synergy water purification system-Merck) is used for all leaching tests.

Regarding the characterization tests, the size distribution of the sand is carried out in accordance with standard UNE EN 933-1, the determination of the apparent density of the cement and white slag is done in line with standard UNE EN 80103. The chemical composition is determined using the X-Ray fluorescent technique, using a Philips PW 2400 Spectrometer, and the Powder Diffraction technique for the mineralogical composition, using an Analytical $X^{\prime}$ pert PRO MPD Alpha 1 (diffractometer in Bragg Brentano $\theta / 2 \theta$ geometry of $240 \mathrm{~mm}$ of radius $\mathrm{Cu}$ Kal radiation $\lambda=1.5406 \AA$ ). Cement and slag size distribution is performed using a

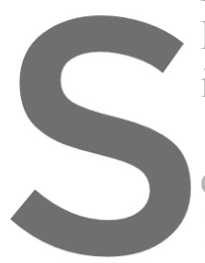
Beckman Coulter LS particle s is used to study the surface struct

The mortars are man

cement ratio of 0.5 in all
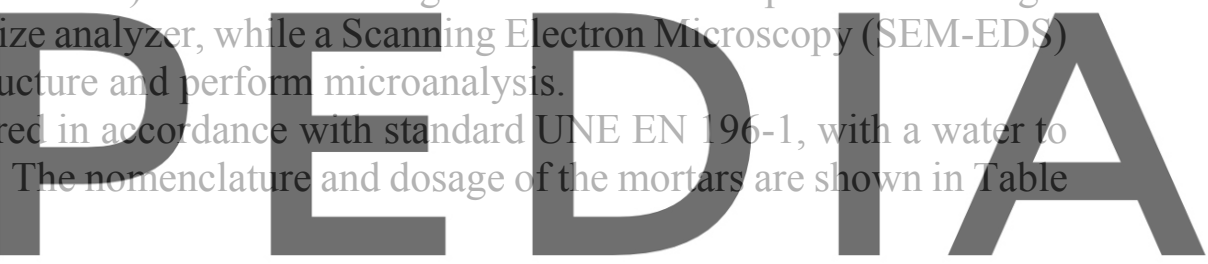

Register for free at Table 1. Dosage and nomenclature of mortars

Table 1. Dosage and nomenclature of mortars.

\begin{tabular}{ccccc}
$\begin{array}{c}\text { Mortar } \\
\text { type }\end{array}$ & $\begin{array}{c}\text { L. Slag } \\
(\mathrm{g})\end{array}$ & $\begin{array}{c}\text { Cement } \\
(\mathrm{g})\end{array}$ & $\begin{array}{c}\text { Sand } \\
(\mathrm{g})\end{array}$ & $\begin{array}{c}\text { Water } \\
(\mathrm{g})\end{array}$ \\
\hline Control & 0 & 450 & 1350 & 225 \\
\hline $\mathrm{M} 75 / 25$ & 337.5 & 112.5 & 1350 & 225 \\
\hline $\mathrm{M} 50 / 50$ & 225 & 225 & 1350 & 225 \\
\hline $\mathrm{M} 25 / 75$ & 112.5 & 337.5 & 1350 & 225 \\
\hline
\end{tabular}

At the ages of 7 and 28 days of curing, density and absorption are determined according to the standard ASTM C642, and the compressive strength according to standard UNE EN 196-1. A length comparator is used to measure the expansion/shrinkage of the mortars over time, which is fitted to the metal points that adhere to the mortars 24 hours after manufacture.

Finally, for the environmental impact tests, standard UNE EN 12457-2 is used for all mortars at the age of 28 days, as well as for white slag. In the case of mortars, they are dried in an oven at $40^{\circ} \mathrm{C}$ to a constant mass, at which point they are ground in a jaw crusher until all the material passes through the $4 \mathrm{~mm}$ sieve. It is then quartered to obtain representative samples. The results of this test are compared with the Decree on waste acceptance criteria in landfills (Council Decision 2003/33/EC of 19 December 2000) to classify mortars as an inert, non-hazardous, or 
dangerous material.

\section{Results and Discussion}

In the following sections, the results obtained from the experimental campaign are analyzed, with emphasis on expansion behavior (durability) and environmental behavior (leaching).

\subsection{Particle Size Distribution and Specific Gravity}

White slag, used in this study, consists of particles between 0.1 microns to 75 microns approximately, granulometry obtained due to a process of grinding the material in a ball mill. Figure 1 shows the size distribution and compares it with the cement used (CEM I 52.5R). It can be seen that the cement has greater fineness from 2 microns to 60 microns, while the slag presents a slightly higher percentage of particles in the range 0.1 to 2 microns.

In Table 2, it can be seen that the density of the slag is lower than the density of the cement (approximately 9\%). This situation will generate a change in the total volumes of mortars manufactured. But for this study, it is assumed that the influence will not change the behavioral trends if the dosage of the mortars is done in weight or volume. In Table 2, it is also observed that sand has an absorption of $1.65 \%$, so it was decided to use this material in the condition of dry saturated surface at the time of manufacturing the mortars.

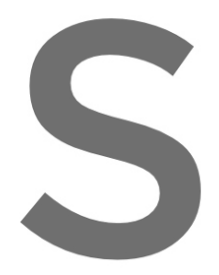

Table 2. Properties of raw materials
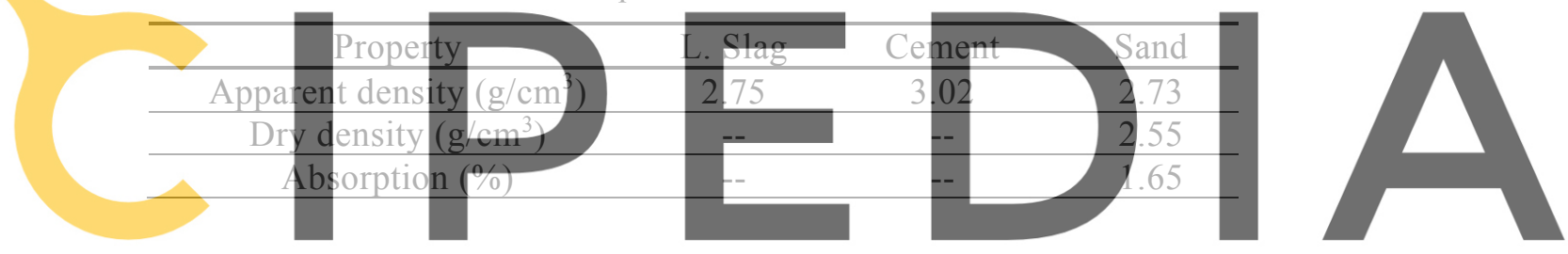

Register for free at https//www.scipedia.com to downlogd the version without the watermark

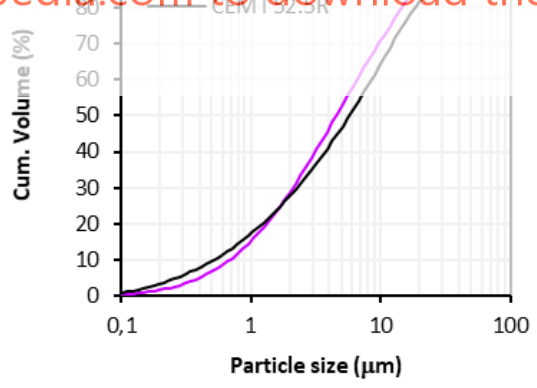

Figure 1. Particle size distribution for Ladle slag and Cement Portland.

\subsection{Chemical and Mineralogical Composition}

Slag and cement basically contain Calcium, Silica, Aluminium, and Iron. White slag has high magnesium content, and some of it may be present as Periclase, which will create expansion problems. Table 3 shows the compounds present in both the slag and the cement. 
Table 3. Chemical composition for Ladle slag and Cement portland.

\begin{tabular}{ccc}
\hline Element & Cement (\%) & L. Slag (\%) \\
\hline $\mathrm{CaO}$ & 63.21 & 46.78 \\
\hline $\mathrm{SiO}_{2}$ & 18.65 & 18.60 \\
\hline $\mathrm{Al}_{2} \mathrm{O}_{3}$ & 3.98 & 6.62 \\
\hline $\mathrm{Fe}_{2} \mathrm{O}_{3}$ & 3.32 & 5.36 \\
\hline $\mathrm{SO}_{3}$ & 2.94 & 1.51 \\
\hline $\mathrm{MgO}$ & 1.42 & 10.85 \\
\hline Others & 1.47 & 1.69 \\
\hline LOI & 5.01 & 8.59 \\
\hline
\end{tabular}

The phases identified in the cement used are: calcium silicates $\left(\mathrm{C}_{3} \mathrm{~S}, \beta-\mathrm{C}_{2} \mathrm{~S}\right)$, calcium aluminate $\left(\mathrm{C}_{3} \mathrm{~A}\right)$, calcium ferroaluminate $\left(\mathrm{C}_{4} \mathrm{AF}\right)$. Anhydrous gypsum $\left(\mathrm{CaSO}_{4}\right)$ and calcite $\left(\mathrm{CaCO}_{3}\right)$ have also been determined. It should be mentioned that the used slag contains a part of amorphous material, together with crystalline phases, such as: calcium silicates ( $\alpha-C 2 S$, $\beta$ $\left.\mathrm{C}_{2} \mathrm{~S}\right)$, calcium aluminate $\left(\mathrm{C}_{3} \mathrm{~A}\right)$, gehlenite $\left(\mathrm{Ca}_{2} \mathrm{Al}\left((\mathrm{AlSi}) \mathrm{O}_{7}\right)\right)$, wustite $(\mathrm{FeO})$, and periclase $(\mathrm{MgO})$. In addition, calcite $\left(\mathrm{CaCO}_{3}\right)$ and in low proportion portlandite $\left(\mathrm{Ca}(\mathrm{OH})_{2}\right)$ and lime $(\mathrm{CaO})$ have been identified.

\subsection{Particle Morphology and Microanalysis}

Figure 2 and Figure 3 show different particles that analysis, the compound example, the calcium silicate compounds show is not possible to speak of compounds $w 1$ th an from the gehlenite fami aluminum in their composition.

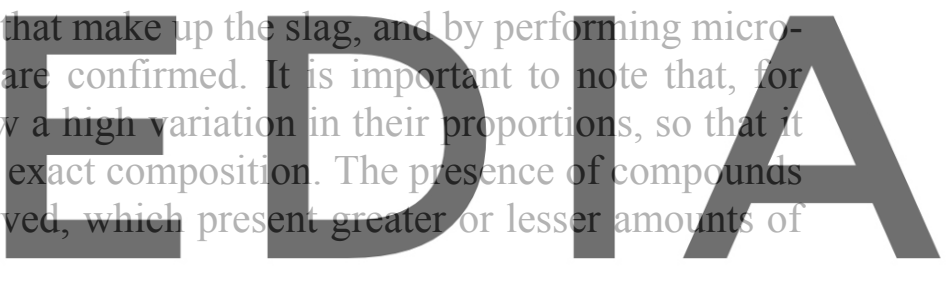

Register for free at https//www.scipedia.com to download the version without the watermark
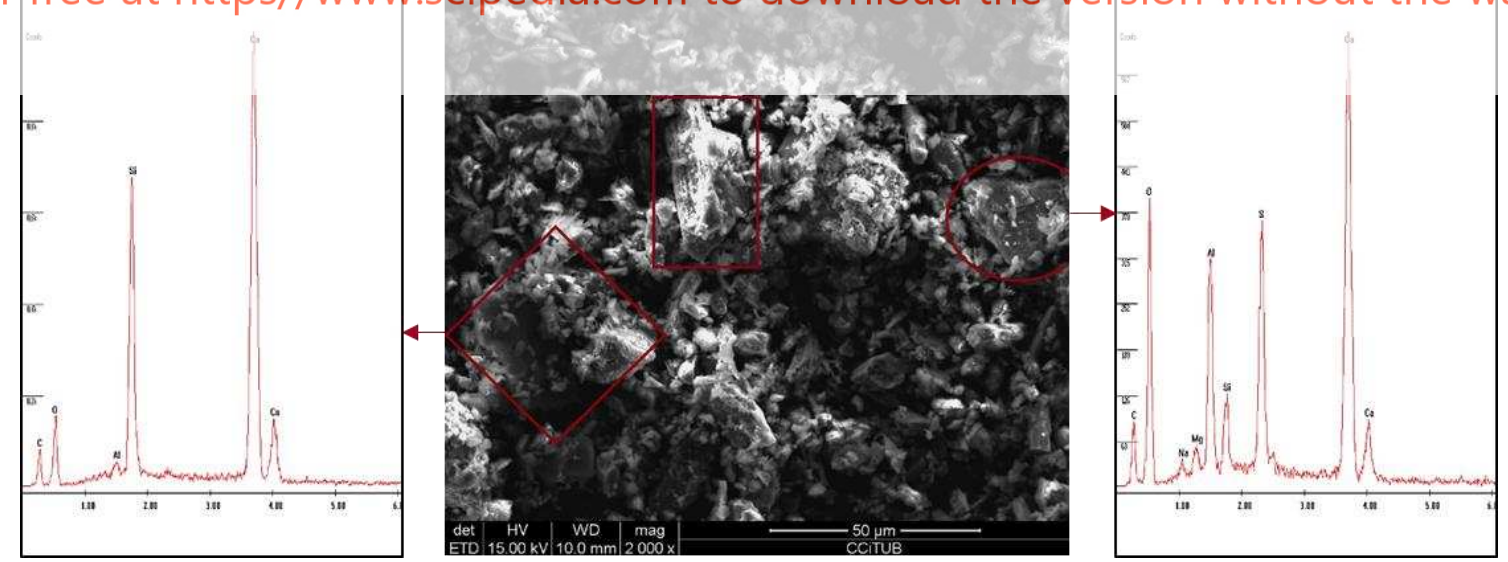

Figure 2. Chemical composition of different Calcium Silicates and Gehlenite of the particle of ladle slag. 

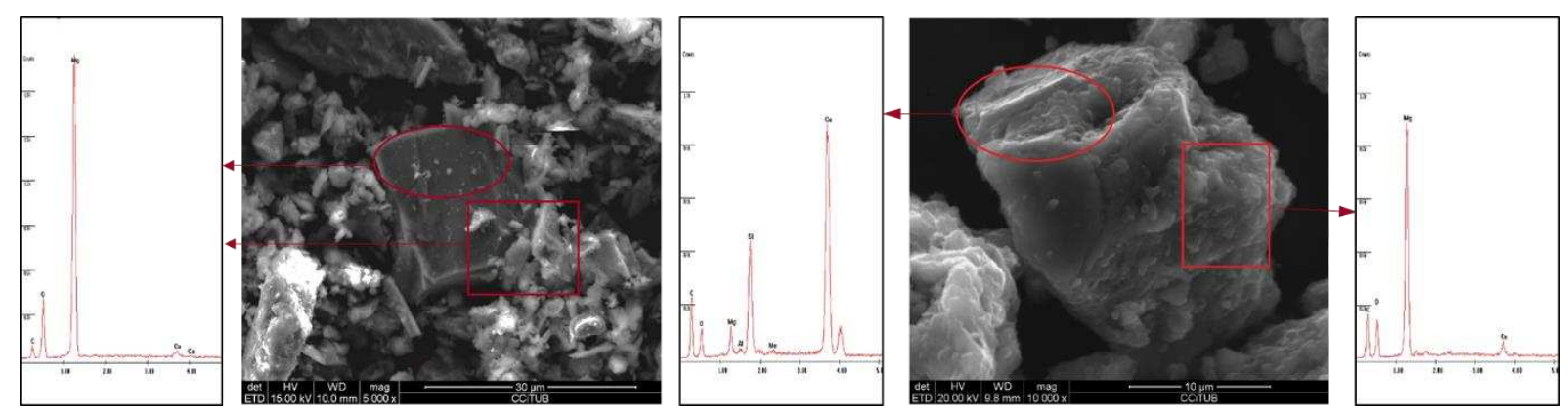

Figure 3. Periclase compound (left) and Calcium Silicate (right) in the Ladle slag.

In the samples analyzed by SEM-EDS, it was possible to find $\mathrm{MgO}$ particles, as shown in Figure 4. Again, the complexity of the mineralogical composition of the slag should be pointed out, since, as shown in Figure 4 right, in the same particle can be found compounds of calcium silicate and magnesium oxide.

\subsection{Physical and Mechanical Properties of Mortars}

As reported in the literature, fine slag has cementitious properties, but with low cementitious activity. This fact has been proved by XRD analyses, where the cementitious compounds are some slow reacting calcium silicates and possibly some gehlenites. Therefore, the particle size of the slag plays an important role in the development of mechanical properties, as it can act as
a filler material.
Figure 4 shows the ef
in compressive strength
decreases, and this decrease
slag, the strength falls
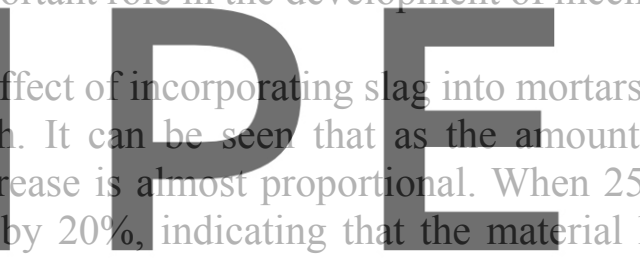
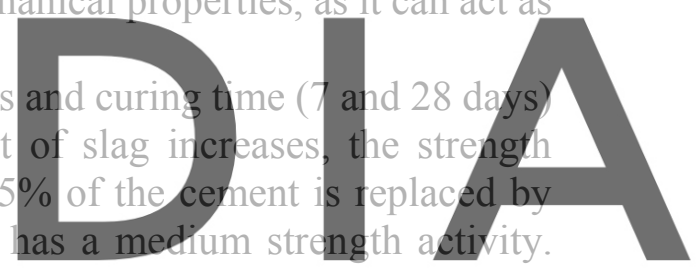

However, when $50 \%$ is replaced, the compressive strength falls by $62 \%$, and when $75 \%$ is

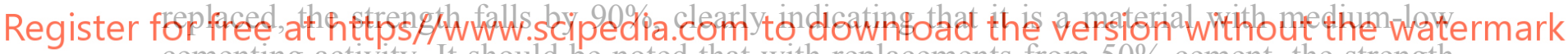
cementing activity. It should be noted that with replacements from $50 \%$ cement, the strength achieved is almost $20 \mathrm{MPa}$, which means that there is a wide variety of materials that could be developed with these properties.

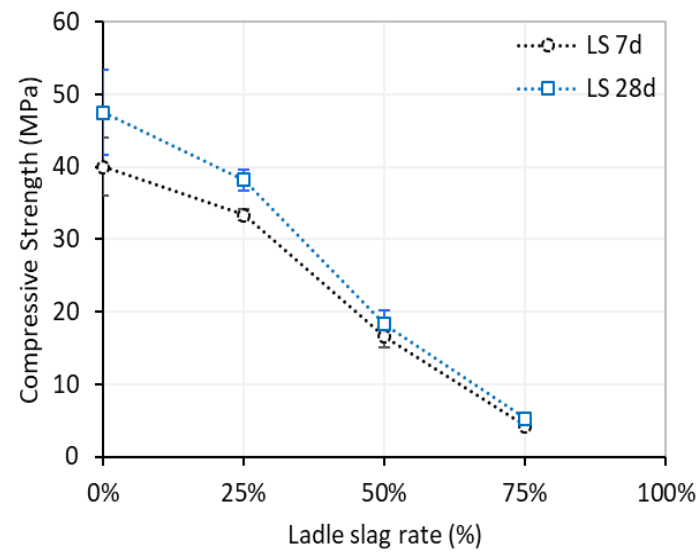

Figure 4. Compressive strength of mortar with different rates of ladle slag. 


\subsection{Expansion Behavior of Mortars}

The volumetric stability behavior has been measured over time up to an age of approximately 400 days. The samples after manufacturing have been kept in a wet chamber $\left(20^{\circ} \mathrm{C}\right.$ and $95 \%$ R.H.), in order to have water availability and to facilitate the reactions of the expansive compounds.

Figure 5 shows the behavior for the different types of mortars (control $=0 \%$ L.S, M25/75 = $75 \%$ L.S, M $50 / 50=50 \%$ L.S, and M75/25 = 75\% L.S.). For the control mortar, a linear increase can be observed up to 100 days, and then the behavior is constant up to $0.02 \%$ linear expansion. For mortars containing slag, it can be seen that after 100 days, linear expansion continues to increase over time, possibly with greater expansion as the slag content increases.

The limit expansion value has been taken as $0.04 \%$, which is used for aggregates with alkalisilica reactivity problems (Velasco, 2014). This is due to the fact that there is no regulation regarding the minimum or maximum expansion that can be accepted when using slags in rigid matrices.
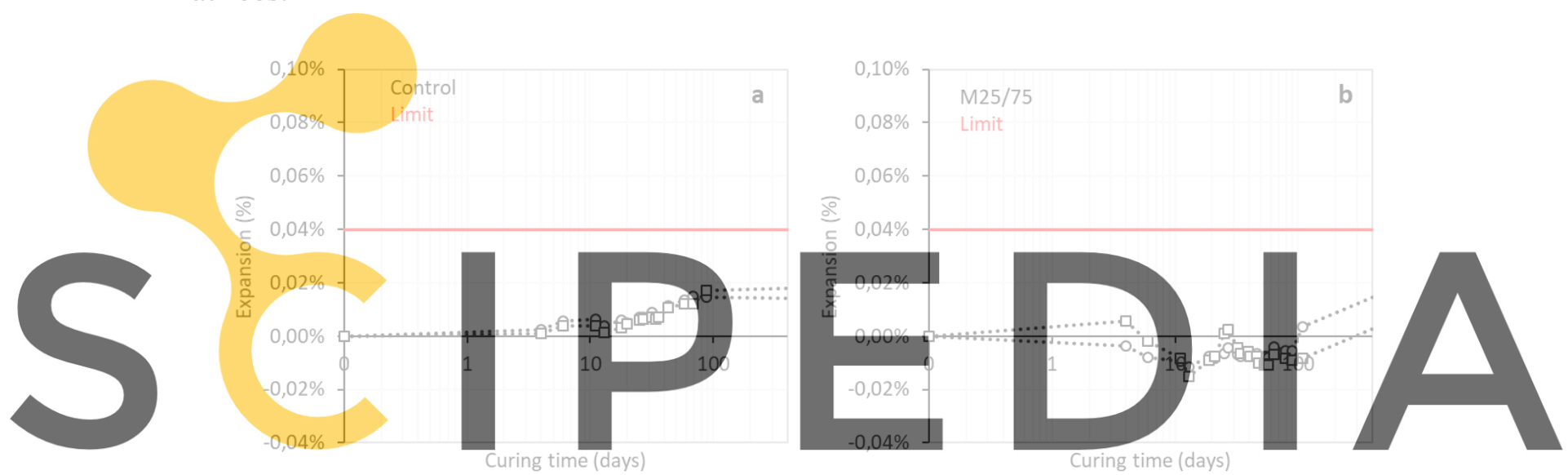

Register for free, at https//Www.scipedia.com to
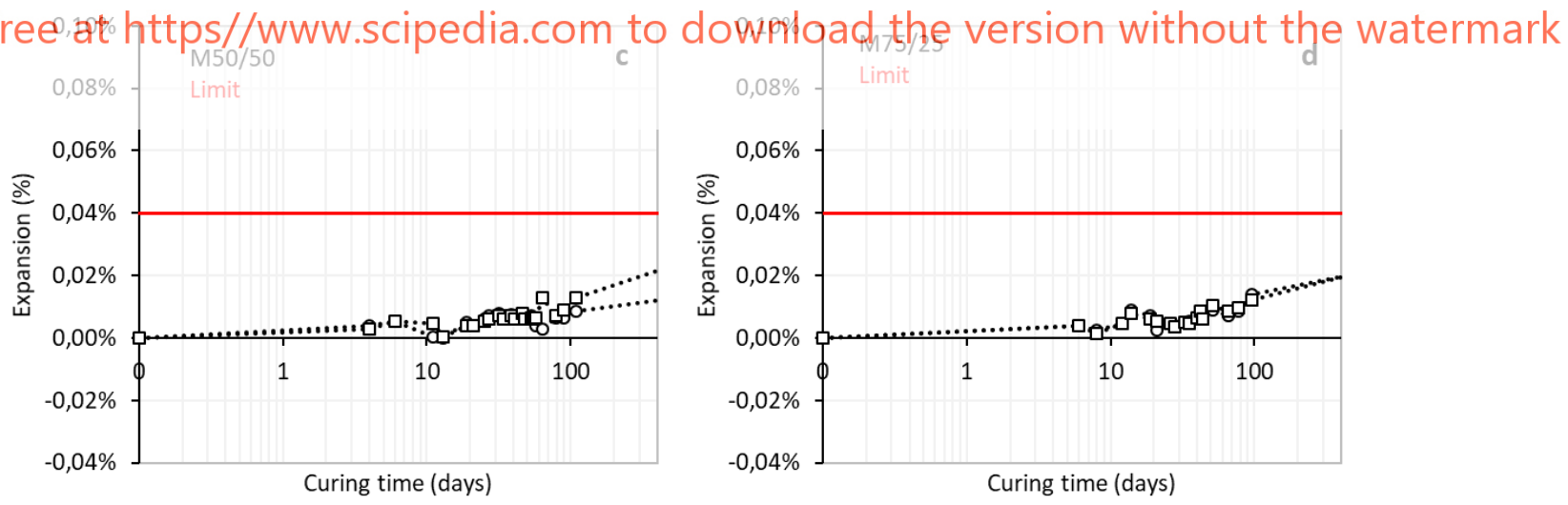

Figure 5. Expansion over time for control mortars (a), 25\% ladle slag mortars(b), 50\% ladle slag mortars (c) and $75 \%$ ladle slag mortars $(\mathrm{d})$.

\subsection{Environmental Behavior of Mortars with Ladle Slag}

In general terms, in Spain and other European countries, slag is classified as an inert waste (REF). However, the classification is open and, in some cases, does not specify whether it is 
black slag or white slag. In this context, some regulations have stated that the classification is only for black slag.

By carrying out leaching tests on the white slag, it can be verified that it is a material that can be in the range of non-hazardous material or hazardous material (Council Decision 2003/33/EC of 19 December 2000), depending on each manufacturing plant. In this study, the white slag analyzed present releases of some elements higher than those accepted for inert materials, such as Barium and Nickel (Fig. 7). However, it can be seen that once incorporated into the mortars, in all proportions, the release is below the limits. Figure 7 shows the quantities released for the elements Chromium, Copper, Molybdenum, Lead, and Zinc, which are below the limits for inert material.

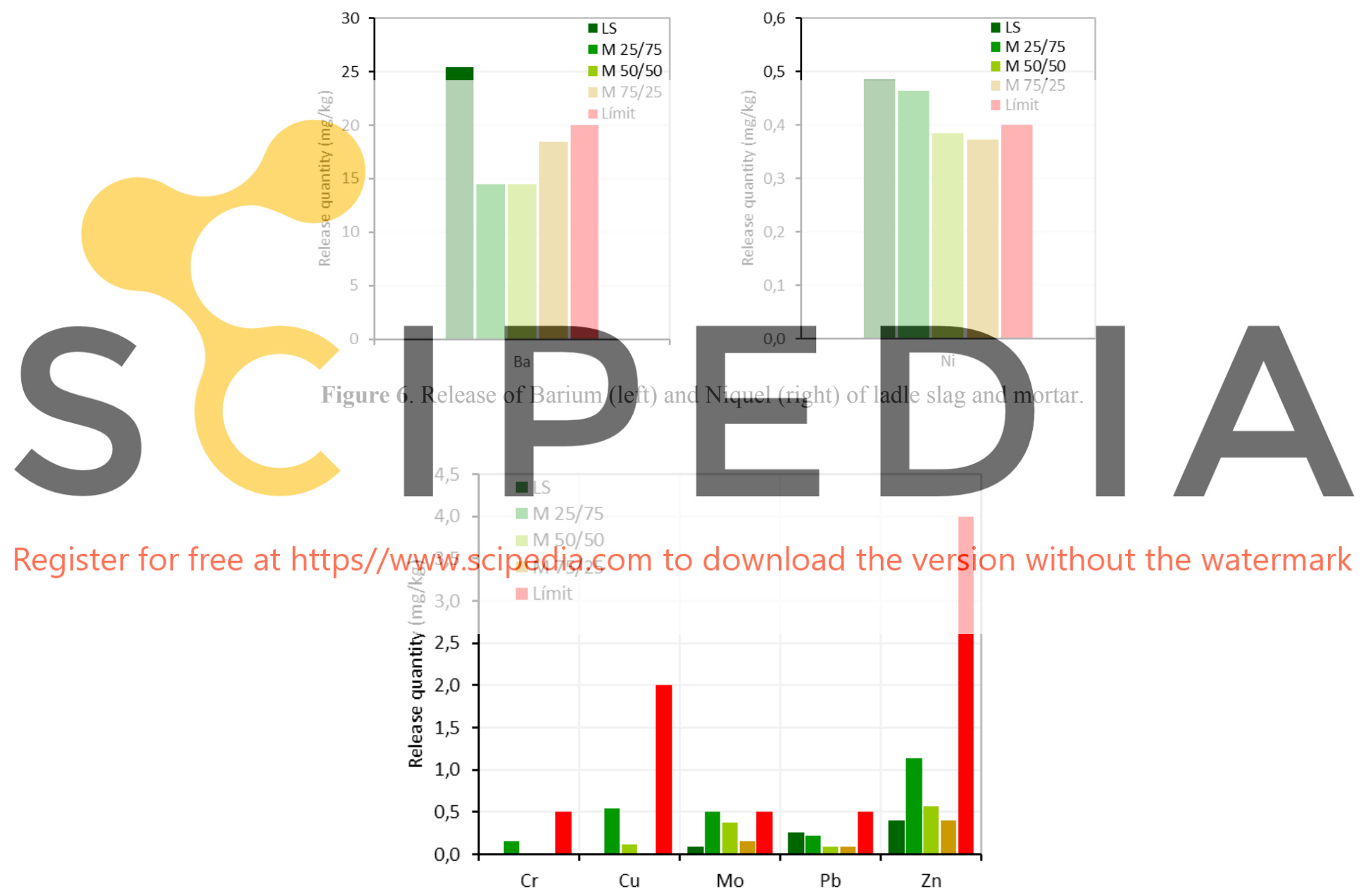

Figure 7. Release of $\mathrm{Cr}, \mathrm{Cu}, \mathrm{Mo}, \mathrm{Pb}$, and $\mathrm{Zn}$ of ladle slag and mortar.

\section{Conclusions}

According to the work done, the following conclusions can be drawn:

- The white slag studied presents phases that can generate cementing behavior. However, it is observed that its activity index is low $(80 \%)$, and it is only working as a filler. 
- Replacement of cement by slag in percentages from $50 \%$ generate materials with a compressive strength between 20 and $5 \mathrm{MPa}$. These values may be thought to be low, but they would allow the use of slag in a wide variety of applications, from low strength fluid fillers $(<2 \mathrm{MPa})$ to low mechanical stress pavement concretes $(15$ to $20 \mathrm{MPa})$.

- The expansive behavior of mortars has shown a tendency to increase over time, which can be a problem in terms of stability. However, linear expansions obtained up to 400 days of curing are below the $0.04 \%$ limit, which raises the possibility of their use in short-life materials.

- The white slag in this study is classified as non-hazardous materials, but when it is incorporated into mortars, it behaves like an inert material. Therefore, at the end of the lifespan of the material, it can be treated without further problems.

\section{ORCID}

Diego Aponte: http://orcid.org/0000-0001-5737-7819

Marilda Barra: http://orcid.org/0000-0002-1417-1615

References

A. Velasco Torres (2014). Estudio experimental sobre la reacción álcali-sílice en el hormigón producida por áridos de reacción lenta. PhD Thesis, Universidad Politécnica de Madrid. Madrid.

D. Adolfsson, F. Engström, R. Robinson, and B. Björkman (2011). Cementitious phases in ladle slag. Steel research Journal, No. 4, p, 398-403.

Eleftherios K. Anastasiou, toanna Papa concrete containing lad

E. Pantazopoulou, and A, Z furnace slag. Journal 15686-8: Buildings ar service-life

J. Mi. Manso, Mi. Losañez, J. A. Polanco, and J. González (2005). Ladie furnace slag in consiruction. Journai of Materials in Civil Engineering, vol. 17, p. 513-518.

K. K. Sideris, Ch. Tassos, A. Chatzopoulos, and P. Manita (2018). Mechanical characteristics and durability of self compacting concretes produced with ladle furnace slag. Construction and Building Materials, vol. 170, p. 660-667.

M. Loncnar, H. A. van der Sloot, A. Mladenovic, M. Zupancic, L. Kobal, and P. Bukovec (2016). Study of the leaching behaviour of ladle slags by means of leaching test combined with geochemical modelling and mineralogical investigations. Journal of Hazardous Materials, n. 317, p. 147-157.

M. Skaf, V. Ortega, J. A. Fuente-Alonso, A. Santamaría, and J. M. Manso (2016). Ladle furnace slag in asphalt mixes. Construction and Building Materials, vol. 122, p. 488-495.

S. Pauliuk, R. L. Milford, D. B. Múller and J. M. Allwood. "The steel scrap age" (2013). Environmental Science and Technology, Vol. 47, p. 3448-3454.

T. Herrero, I. Vegas, A. Santamaria, J. T. San-Jose, M. Skaf. Effect of high alumina ladle furnace slag as cement susbtitution in masonry mortars (2016). Construction and Building Materials, vol. 123, p. 404-413.

V. Ortega-López, J. M. Manso, I. I. Cuesta, and J. González (2014). The long term accelerated expansion of various ladle furnace basic slag and their soil stabilization applications. Construction and Building Materials, vol. 68, p. 455-464. 